\title{
ISLAMIC LEADERSHIP AND MAQASID AL-SHARI'AH: REINVESTIGATING THE DIMENSIONS OF ISLAMIC LEADERSHIP INVENTORY (ILI) VIA CONTENT ANALYSIS PROCEDURES
}

Mahazan, A.M. ${ }^{1^{*}}$, Nurhafizah, S. ${ }^{2}$, Rozita, A. ${ }^{3}$ Siti Aishah, H. ${ }^{4}$, Wan Mohd. Fazrul Azdi, W.R. ${ }^{5}$, Mohd. Rumaizuddin, G. ${ }^{6}$, Yuseri, A. ${ }^{7}$, Mohd. Rosmizi, A.R. ${ }^{8}$, Muhammad, H. ${ }^{9}$, Mohd. Azhar, I.R. ${ }^{10}$, Abdullah, A.G. ${ }^{11}$, Muhammad Yusuf, K. ${ }^{12}$, Khairunneezam, M.N. ${ }^{13}$

${ }^{1}$ Dr., Faculty of Leadership and Management, Universiti Sains Islam Malaysia, MALAYSIA, mahazan@usim.edu.my

${ }^{2}$ Dr., Faculty of Leadership and Management, Universiti Sains Islam Malaysia, MALAYSIA, nurhafizah@usim.edu.my

${ }^{3}$ Dr. Faculty of Leadership and Management, Universiti Sains Islam Malaysia, MALAYSIA, rozita@usim.edu.my

${ }^{4}$ Ms., Faculty of Leadership and Management, Universiti Sains Islam Malaysia, MALAYSIA, aishah.hussin13@gmail.com

${ }^{5}$ Mr., Faculty of Leadership and Management, Universiti Sains Islam Malaysia, MALAYSIA, wmfazrul@usim.edu.my

${ }^{6}$ Assoc. Prof. Dr, Faculty of Leadership and Management, Universiti Sains Islam Malaysia, MALAYSIA, rumai@usim.edu.my

${ }^{7}$ Mr., Faculty of Leadership and Management, Universiti Sains Islam Malaysia, MALAYSIA, yuseri@usim.edu.my

${ }^{8}$ Dr., Faculty of Leadership and Management, Universiti Sains Islam Malaysia, MALAYSIA, rosmizi@usim.edu.my

${ }^{9}$ Mr., Faculty of Leadership and Management, Universiti Sains Islam Malaysia, MALAYSIA, muhammad@usim.edu.my

${ }^{10}$ Mr., Faculty of Leadership and Management, Universiti Sains Islam Malaysia, MALAYSIA, azhar@usim.edu.my

${ }^{11}$ Prof. Dr, College of Business, Universiti Utara Malaysia, MALAYSIA, abd129@uum.edu.my

${ }^{12}$ Assoc. Prof. Dr., Faculty of Leadership and Management, Universiti Sains Islam Malaysia, MALAYSIA, yusuf@usim.edu.my

${ }^{13}$ Dr., Faculty of Leadership and Management, Universiti Sains Islam Malaysia, MALAYSIA, neezam@usim.edu.my

${ }^{*}$ Corresponding author 


\begin{abstract}
The purpose of this research is to investigate separate themes of Islamic Leadership based on analyses conducted on selected literature of conventional and Islamic Leadership. The themes of Islamic Leadership were identified for the purpose of developing a specific inventory to measure Islamic Leadership or the Islamic Leadership Inventory (ILI). In identifying the themes of Islamic Leadership, this research applied qualitative content analysis procedures on four categories of literature. The literature are (1) The Qur'an and Hadiths (2) Managerial Leadership and Servant Leadership literature (3) Contemporary Islamic Leadership literature (4) Classical texts of Islamic Leadership. This research used NVIVO to facilitate information processing. With respect to the underlying theory of research, this research is based on the principles of higher objectives of Shari'ah or the Maqasid al-Shari'ah to justify the importance of the identified Islamic Leadership behaviors from the lenses of Islam. Based on the content analysis, this research found 25 separate themes representing Islamic Leadership Behaviours. The 25 themes are (1) Trustworthiness and Integrity, (2) Employees Orientation, (3) Self-evaluation, (4) Patience, (5) Outcome Orientation, (6) Empowerment, (7) Social Responsibility (8) Flexibility (9) Non-Calculative, (10) Spirituality, Religiousness and Piety, (11) Esprit De Corps, (12) Bravery, (13) Justice and Equity, (14) High Self-Reliance and High SelfEsteem, (15) Modesty and Shyness, (16) Impartially, (17) Moderation and Balance, (18) Good in Communication, (19) Free from environmental-constrains, (20) Earnest, (21) Cheerful, (22) Feared when angry, (23) Empowering Intelligent, Wisdom and Encourage Synergy, (24) Role Model, and (25) Avoid Conflict. The themes suggested could be used to measure Islamic Leadership in various perspectives. In general, this paper offers policymakers, organisations, and researchers in various avenues the important dimensions of Islamic Leadership. Specifically, the Islamic Leadership Inventory (ILI) could be utilised to measure the effectiveness of Muslims' professionals based on the perspectives of Islam and the higher objectives of Shariah. In sum, this paper found that Islamic Leadership could be represented in several dimensions and could be adapted in the conventional measures of managerial leadership.
\end{abstract}

Keywords: Islamic Leadership Inventory, Leadership Behaviour, Leadership Approaches

\title{
1 INTRODUCTION
}

The current development of leadership theories and models has moved researchers to revisit some of the fundamental and underpinning philosophies. The movement has enlightened researchers to incorporate spiritual elements in the development of leadership concepts and theories (Khaliq, 2011; Abdul Rashid, 2011; Bird, Ji, \& Boyatt, 2004). Nevertheless, the efforts of those scholars were insufficient in exploring and emphasizing the religious practices and values among leaders (Badawi \& Beekun, 1999).

Although there are researchers who have investigated the importance of religiosity towards leadership (see Shee, Ji, \& Boyatt, 2002), the researchers only incorporate certain religious values of leaders in studying the leaders' managerial and leadership behaviours. Furthermore, the religiosity and spirituality elements are rarely integrated with current development of managerial leadership behaviour measures. The lack of integration has caused the variables (i.e. religiosity and spirituality) to be perceived as distinct but interrelated with leadership behaviour.

The Islamic Leadership Inventory or ILI acts as a measure of effective Islamic leadership behaviour. Theoretically, this could be done by integrating a list of behaviours that have been identified as important for organisational leaders with behaviours that have been emphasized in classical and modern literatures discussing leadership in Islam. In other words, ILI is expected to act as a set of Islamic leadership behaviour taxonomy, which consists of dimensions or constructs that are uniquely related to Islamic Leadership. Based on its theoretical foundation, each of the dimensions in ILI consists of both effective leadership and Islamic leadership behaviour items, which could help researchers explore the concept of Islamic leadership behaviour in various contexts and settings.

This research, therefore, provides an argument that religious philosophies could be manifested in several dimensions and could be adapted in the conventional measures of managerial leadership. Moreover, this research demonstrates a clear pattern of Islamic leadership behaviour inventory or could be established by applying the measure to a group of executives and professionals in business and non-business organisations. As briefly discussed above, in the case of Islamic Leadership Inventory or ILI, this research 
contends that the process of developing the inventory should commence by conducting a structured procedure to analyse conventional literature on managerial leadership theories and practices. In performing the analysis, this research organised the differences between conventional managerial leadership behaviour theories and practices with Islamic leadership concept through hermeneutics content analysis (Neuman, 1997). The content analysis was conducted on some selected literature of Islamic Leadership, Servant Leadership, Managerial Leadership, The Qur'an and Hadiths and together with the classical texts of Islamic Leadership.

Managerial leadership literature was used to provide critical dimensions of managerial leadership behaviour in the attempt to frame the content analysis in a more organizational-centric manner (Yukl, 2013; Yukl, Gordon, \& Taber, 2002). The dimensions of Islamic Leadership and Servant Leadership arose from three scholastic arguments pertaining to the concept of Servant Leadership, which has become the impetus to adopt a content analysis in this study.

Firstly, Badawi and Beekun (1999) contend that the underpinning ideas of Servant Leadership concept have been outlined in the teachings of Islam. Secondly, Humphreys (2005) argues that the concept of Servant Leadership is only practical in static environments. Finally, Whetstone (2002) further argues that the concept of Servant Leadership is insufficient to be used on employees or followers who are less-naive and are capable of exerting excessive and self-interest influence on leaders.

On the basis of the above arguments, particularly the first one, this research aims to enrich the understanding of Servant Leadership by examining it from the perspectives of Islamic Leadership. The basic dimensions of the analysis are expected to be Islamic Leadership while incorporating Servant Leadership items. In a similar vein, the understanding of Managerial Leadership will frame the analysis in order to maintain its organisational-centric nature. In line with the aim of this research, the development of a specific inventory of Islamic Leadership will be utilized among executives and leaders of organisations. Figure 1 clearly depicts the relationship between the three concepts:

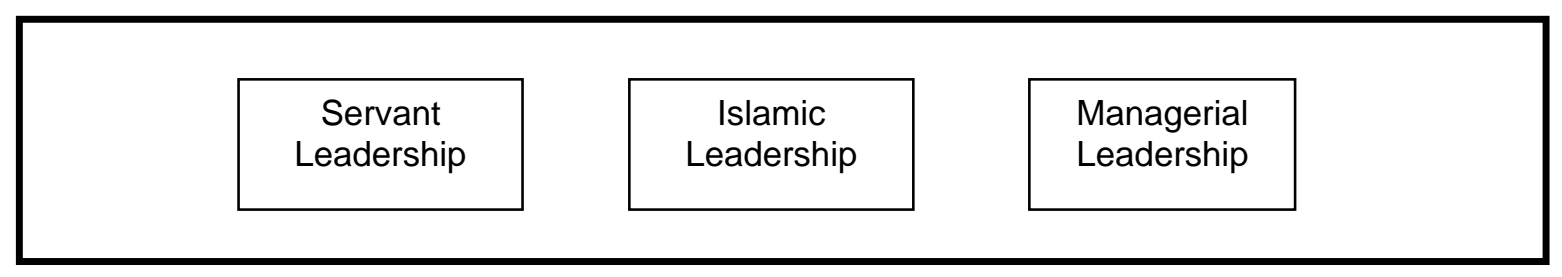

Fig. 1: Islamic Leadership as the Centre of Managerial Leadership and Servant Leadership

\section{THE CONCEPTS AND THEORIES}

This section discusses the higher objectives of Shariah or the Maqasid al-Shari'ah to underpin the understanding of Islamic Leadership. This section also discusses two other basic concepts of ILI, or the Islamic Leadership itself, and Managerial Leadership Theory.

\subsection{Maqasid Al-Shari'ah}

Maqasid al-Shari'ah refers to the understanding of the meaning and goals of the Shari'ah in every law. AlFasi (2011) defines Maqasid al-Shari'ah as to understand the Islamic belief and goals from the Shari'ah perspective in addition to the unfolding secrets in any given matter as prescribed by Islamic law. Knowledge of Maqasid al-Shariah is essential for a mujtahid when delivering opinions, especially when there are differences in opinions (Al-Fasi, 2011, p. 111; al-Ghali, 1996, p. 120). Ibn 'Ashur defines Maqasid alShari'ah as a wisdom and all the emphases in the laws are prescribed as a whole or in substantial part. Meanwhile, al-Raisuni defines Maqasid al-Shari'ah as the objectives to be achieved by the Islamic law for the benefits of humanity. He divides Maqasid al-Shariah into three categories unlike most other scholars who divided Maqasid into two parts which is the general Maqasid and the specific Maqasid. Al-Raisuni has added Maqasid Juz'iyy (i.e. part or fragment) (al-Raisuni, 1992, p. 18; al-Raisuni, 2009, p. 28; al-Raisuni, 2010, pp. 10-12). Maqasid al-Shari'ah is the study of intention and the unfolding secrets of the al-Shari'ah and its laws for the benefit of mankind either by beneficial way or to avoid harm in this world and the hereafter. 
Maqasid means purpose, requirements or goals. Specifically, in Islam, it refers to goals, outcomes or purposes that are required by Islamic law by decree of resources through the Qur'an or the Sunnah. It can also be defined as creating good and to avoid and eliminate harm. Al-Raisuni defines Maqasid as the objectives set by Islamic law to fulfil the interests of the human race (maslahah). Thus, Maqasid is the purpose and connotation prescribed by Islamic law in every legal either in general or specific term, to safeguard the interests of humanity (al-Qaradawi, 2006, p. 1; al-Raisuni, 1992, p. 25; al-Raisuni, 2010, p. 7; Ibn 'Ashur, 2009, p. 55).

Other practices of Maqasid al-Shari'ah include upholding justice, equality, facilitating and make ease, to bring good and avoid harm, unity and solidarity. Ibn 'Ashur mentions that amongst the most important purposes of the laws is to protect human life and to improve system towards a respectable aspect of thought, work and relationships with other people in creating a perfect life (Ibn 'Ashur, 2009, p. 168). For instance, Islam prohibits various types of wine made produce, including others made from other than grapes with the intention to keep a good intellect. Commercial drugs use is also prohibited because it eradicates mind and leads to a waste of possessions. Moreover, a judge in the court is forbidden to give a sentence when he or she is hungry and in anger because both conditions will result in a loss of judgment and concentration.

\subsection{Islamic Leadership}

Islamic Leadership is almost identical to conventional leadership besides in its religious, moral, and human roots (Khaliq \& Ogunsola, 2011). Mankind as the vicegerent of God, the Most High (al-'Ali), represents Him in the task of comprehending, conveying and executing the stipulated rules of Allah SWT. Man act as leaders in its varieties of level: upon self, family, neighbourhood or state; and areas: religion, education, politics, economics and armed forces. (Al-Zuhayli, 1418H, pp. 122-135).

In the Qur'an and the Sunnah, the issues of leadership have been mentioned in many ways, either by emphasizing on its principles or examples. The word Imam, which means leader in its many forms such Imam, Imaman, Imamihim and A'immah, has been mentioned 11 times in the Qur'an and innumerably in the Sunnah (Muhammad Fu'ad, 2001). Besides the word imam or leader, al-Qur'an al-Karim also discussed bad leadership. For example, Surah Al-Naml 27: verse 34; Allah SWT described bad leadership in the story of Queen Balqis: "She said: "Kings, when they enter a country, despoil it, and make the noblest of its people, its meanest thus do they behave." Thus, it should be understood that in Islam, leadership should not only be perceived from the standpoint of the effective leadership process but also from the perspectives of how a leader could be perceived as bad and sinful.

Leaders in Islam should understand that there are greater rewards to be sought other than financial and material gains. The true objectives embedded in the Maqasid al-Shari'ah require Islamic Leadership in the spirit of the religion to ensure not only to be successful in this world but also in the hereafter.

\subsection{Managerial Leadership}

The research on conventional managerial leadership is generally aimed to investigate the extent to which a leader is able to exert his or her influence towards the followers in multiple or across organizational levels (Hunt, 1991; Yukl, 2013). Although there were disagreements in categorising leaders in different levels of managerial positions (Hunt, 1991), the confusion does not hinder researchers' interest to study leadership from multiple perspectives. Leadership researchers were emphasized to focus on multilayers of leaders and through a variety of methodologies in disseminating information with regard to leadership or leadership practices (Yukl, 2013).

Scholars also argued that the previous leadership researchers mainly focused on theory- building that were based on experiments or observations conducted on non-leaders (i.e; college students) (Yukl, 1989; 2013). Undeniably, the approach has vastly contributed to the development of leadership theories and models. Nevertheless, continuous efforts should be carried out by further investigating the information obtained in laboratories on leaders from multiple levels and across organizations. Thus, based on the critiques and gaps found in the literature, this current research aims to expand previous theories and researches on organizational leadership. This research aims to investigate the issue of effective managerial leadership practices from the perspective of conventional managerial leadership and Islamic leadership. Furthermore, the findings of this research are expected to be able to bridge the gap between the arts of Islamic leadership (that has been thoroughly discussed in some classical Islamic literature) and modern leadership practices. 
The Islamic Leadership Model that will potentially be developed in this research utilizes the data that will be obtained from Malaysian Muslims managers and leaders in various organisations. This research proposes to conduct the analysis on modern leadership theories and practices from the Islamic leadership viewpoints and investigate them upon contemporary Muslim leaders and managers. This approach of analysis could facilitate a greater understanding of Islamic leadership.

\section{RESEARCH METHODOLOGY}

This research applied content qualitative analysis procedures. The focus of the content analysis in this research is to revisit the concept of Islamic Leadership that was discussed in conventional literature. This was done by investigating the concept through its original sources, i.e. the Qur'an and Hadiths. Conventional concepts of Islamic Leadership that were published in several literature (Badawi \& Beekun, 1999) could be argued as practical but require further investigation. This could be done by linking the concept to its original sources (i.e. the Qur'an and Hadiths) as well as to select classical Islamic Leadership texts. Classical Islamic Leadership texts were utilised to justify and enrich the conventional idea of Islamic Leadership. This was also done by justifying the themes of Islamic Leadership based on the understanding of Maqasid al-Shari'ah.

In previous research, the characteristics of Islamic Leadership were compared to the characteristics of Servant Leadership and Managerial Leadership. The research was mainly conventional since it only used recently published Islamic Leadership literature. This research continues to investigate ILI by revisiting the concept based on the four categories of literature as mentioned above and the understanding of Maqasid alShari'ah.

\subsection{Data Collection Procedure}

In line with inductive procedure, the data were obtained from secondary sources: data derived from academic and non-academic literature. This research outlined five phases of analysis as the part of the process which was based on content analysis. The qualitative software called NVIVO was used to facilitate the organization of data and themes. The process starts when this study begins to identify and look for patterns of meaning and issues of potential interest in the data (Braun \& Clarke, 2006). The process of analysis involves a constant moving back and forth between the entire data set. Meanwhile the data obtained from the literature were extracted and coded in order to search for and eventually produce Islamic Leadership themes (Braun \& Clarke, 2006).

Specifically, this research applied inductive approach in identifying specific themes of Islamic Leadership. Through an inductive approach, this research content-coded four categories of literature: (1) The Qur'an \& Hadiths, (2) Managerial Leadership and Servant Leadership literature, (3) Contemporary Islamic Leadership literature, and (4) Classical texts of Islamic Leadership. In doing content analysis, this study used a qualitative software called NVIVO to facilitate information processing.

\subsection{Data Analysis Procedure}

This research conducted five phases of analyses to identify the Islamic Leadership themes based on the four categories of literature: (1) The Qur'an \& Hadiths, (2) Managerial Leadership and Servant Leadership literature, (3) Contemporary Islamic Leadership literature, and (4) Classical texts of Islamic Leadership. The procedure was adopted from Braun and Clarke (2006). The five phases of analyses used in this research are as follows: (1) Familiarization with the data from the above-mentioned literature, (2) Generating initial codes by revisiting the Qur'an and Hadiths along with other Islamic literature to reshape the dimensions of ILI. As a result of extensive analysis of the selected Islamic literature (i.e. the Qur'an, Hadiths, and classic Islamic Literature), this research has identified 25 themes of Islamic Leadership Inventory (ILI). (3) Searching for themes when all data extract have been coded and collated. During this phase, the study has to re-focus on the analysis of themes or repeated patterns in a broader perspective rather than codes (Braun \& Clarke, 2006). Phase (4) Reviewing themes involves one important level, which is to review at the level of the coded data extracts. In other word, the study needs to read all the collated extracts for each theme, and to consider whether they appear to form a coherent pattern. During this phase, the research also has to consider the validity of individual themes in relation to the data set (Braun \& Clarke, 2006). Phase (5) concludes by defining and naming the themes, the research could identify the essence of what each theme is about and determining what aspect of the data each theme captures and naming the themes (Braun \& Clarke, 2006). Defining the themes involves a rigorous exercise among the research team members in order to produce an accurate representation of the data set. The research team, which consists 
of academics from different knowledge backgrounds and academic fields (Islamic leadership, Theology, Communication studies and Psychology) had reflective and thorough discussions in order to maintain rigour in the analysis.

Table (1) depicts an example of data extracted and its code name to measure specific themes of Islamic Leadership. The process of deriving the themes involved a thorough examination of every juz' in the Qur'an and from Hadiths and other classical text of Islamic literature. Meanwhile, Figure (2) shows the 25 themes of the Islamic Leadership Inventory which were derived based on the analysis that have been conducted.

Table 1

\begin{tabular}{|c|c|}
\hline Items & Coded for \\
\hline $\begin{array}{l}\text { 1. To not betray the trust (Al-A'raf: } 27) \\
\text { Item: } \\
\text { a. I strive to fulfil the organization's trust. } \\
\text { b. I lead by following the guideline set by the organization. }\end{array}$ & Trustworthiness/ Integrity \\
\hline $\begin{array}{l}\text { 1. Advising (Al-A'raf: 62.79) } \\
\text { Item : } \\
\text { a. I advise my employees to do good things. } \\
\text { b. I advise my employees about religious matter. }\end{array}$ & Employees Orientation \\
\hline $\begin{array}{l}\text { 1. Leadership is a test }(A l-A n ' a m: 164) \\
\text { Item : } \\
\text { a. I realize that rank is a test from Allah SWT. } \\
\text { b. Leadership ranks will be followed by severe punishment, if not } \\
\text { conducted fairly. }\end{array}$ & Muhasabah (Retrospection) \\
\hline $\begin{array}{l}\text { 1. Avoid making decisions when angry (Al-A'raf: } 154) \text { Item : } \\
\text { a. I refrain from making a decision when I was in anger. } \\
\text { b. A decision should be made after the anger has eased. }\end{array}$ & Patience \\
\hline
\end{tabular}




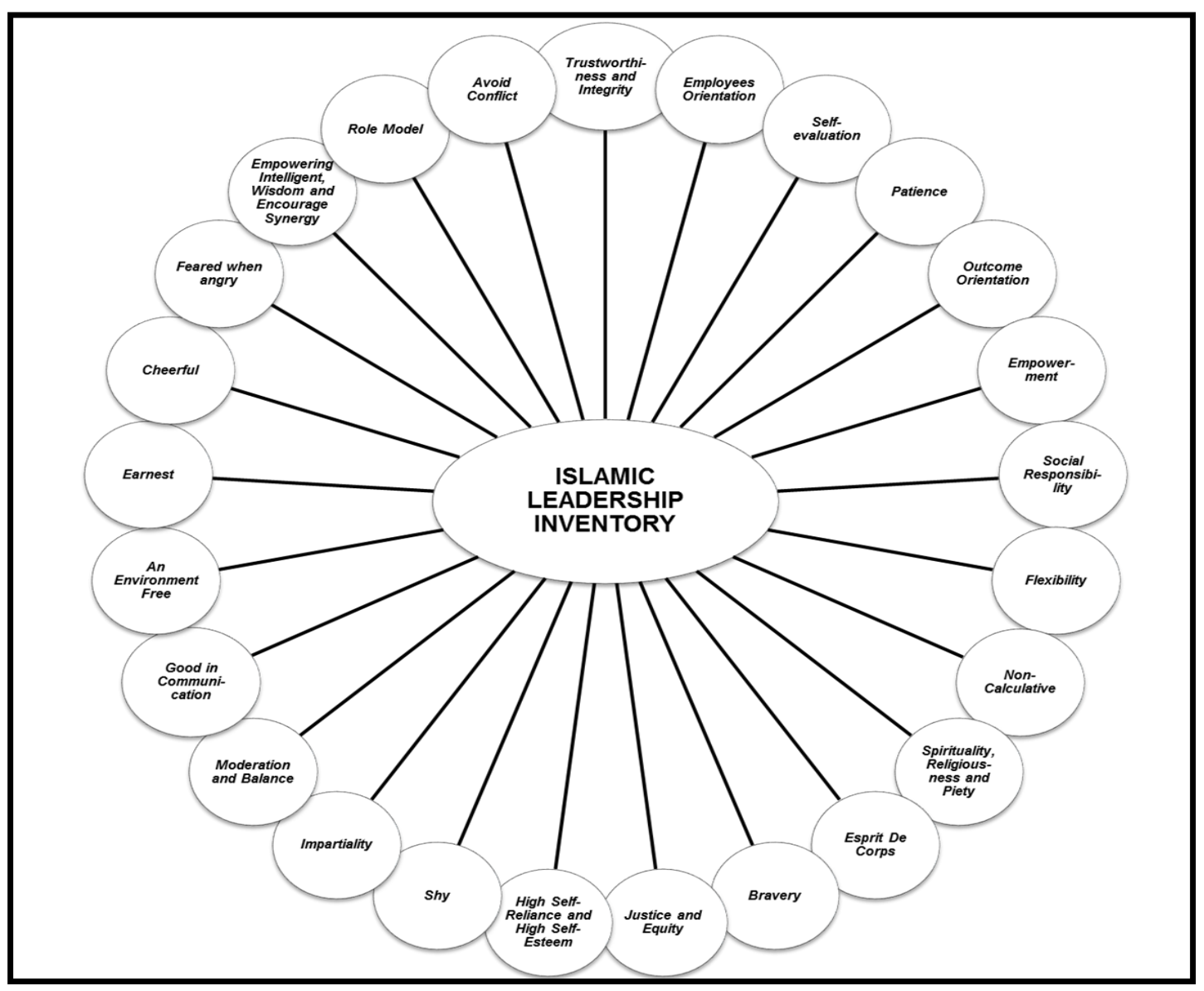

Fig.2: 25 Themes of Islamic Leadership Inventory as Identified in this Research

\section{RESULTS AND DISCUSSION}

Based on the content analysis procedures as discussed above, this research has identified 25 separate themes of Islamic Leadership behaviour (Figure 2). Qualitative research involves a series of questions, and there is a need to be clear about the relationship between these different questions (Braun \& Clarke, 2006). As a result of using NVIVO to facilitate information processing, this research has removed many if not most of the clerical tasks associated with the manual coding and retrieving of data (Shahzad \& Malik, 2014). The 25 themes are (1) Trustworthiness and Integrity, (2) Employees Orientation, (3) Self-evaluation, (4) Patience, (5) Outcome Orientation, (6) Empowerment, (7) Social Responsibility (8) Flexibility (9) Non-Calculative, (10) Spirituality, Religiousness and Piety, (11) Esprit De Corps, (12) Bravery, (13) Justice and Equity, (14) High Self-Reliance and High Self-Esteem, (15) Modesty and Shyness, (16) Impartially, (17) Moderation and Balance, (18) Good in Communication, (19) Free from environmental-constrains, (20) Earnest, (21) Cheerful, (22) Feared when angry, (23) Empowering Intelligent, Wisdom and Encourage Synergy, (24) Role Model, and (25) Avoid Conflict.

This research is conducted to ensure that the 25 Islamic Leadership Inventories themes are integrated with the previous 19 themes of Islamic Leadership found in the earlier studies by Mahazan and Wan Mohd Fazrul Azdi (2012). The new themes derived from this study further extend the understanding of Islamic Leadership and how it evolves over time. This could be seen from the categories of literature used in the content analysis of both researches. In one hand, the first 19 themes were identified based on content analysis conducted on three categories of literature or first contemporary Islamic Leadership literature, secondly, Servant Leadership literature, and thirdly, Conventional Leadership literature. On the other hand, the newly identified 25 themes of Islamic Leadership expand the first study by including the fourth category of literature or Classical Islamic Leadership literature.

Apart from that, this research is performed to ensure the selected 25 themes of ILI is in accordance with the concept of Maqasid al-Shari'ah. In the philosophy of Maqasid al-Shari'ah, there are 5 principles of Maqasid 
(foundation goals) that a person or organization needs to fulfil before making any decisions or actions. These 5 principles are: (1) Preservation of Religion, (2) Preservation of Life, (3) Preservation of Intellect, (4) Preservation of Progeny, and (5) Preservation of Property. These five (5) necessities are derived from the Shari'ah and vital for every human existence (Al-Allaf, 2013). Each theme in the ILI should be aligned with the philosophy of Maqasid al-Shari'ah to form a foundation in Islamic leaders. It is crucial for Muslim leaders to fulfil the 25 characteristics in the Islamic Leadership Inventory. These 25 themes are necessities for every Muslim leader, as any acts of corruption among Muslim leaders in the current Muslim world are considered intolerable and disavowed. Leaders, as described in Islam, need to carry responsibility bestowed by Allah SWT upon them and at the same time carry on their shoulders the trust to serve the organisation and society.

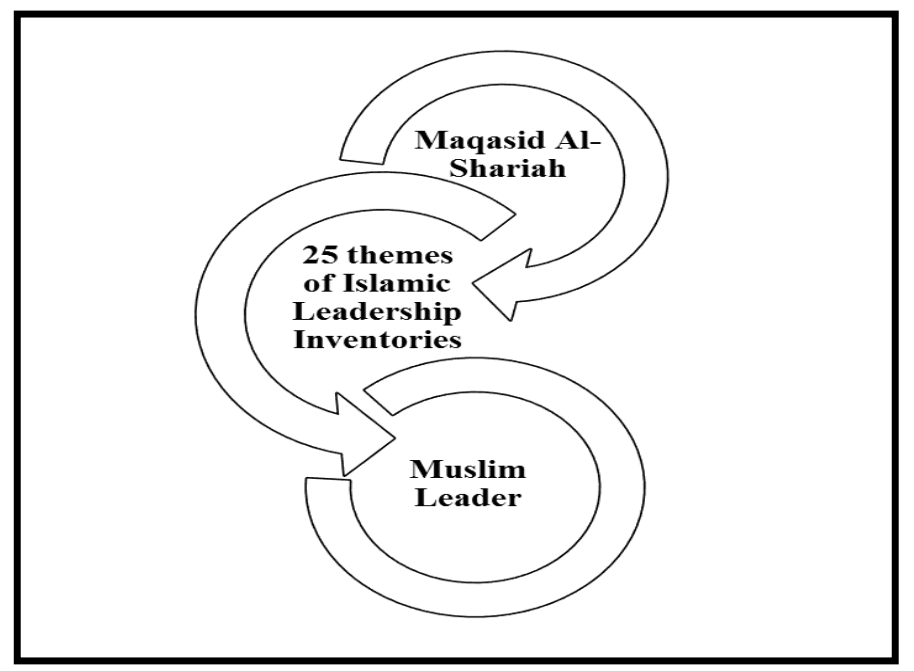

Fig. 3: Maqasid al-Shari'ah and Islamic Leadership Inventories as the Foundation for Muslim Leaders

Based on the theoretical framework (Figure 2), Islamic Leadership Inventories are grounded with the principle of Maqasid al-Shari'ah and these ILI will be the basis for the formation of Muslim leaders. This point could at least be understood in two ways. First, as discussed above, the Maqasid al-Shari'ah provides a basis of understanding to identify important areas of action that need to be stressed. In other words, Maqasid al-Shari'ah provides the underlying framework of an individual's actions by highlighting certain aspects that need to be considered and avoided. Secondly, the 25 themes were identified based on the content analysis conducted on the holy scripture of Islam (the Qur'an), the words of Prophet Muhammad SAW, and classical as well as conventional Islamic Leadership literature. The analysis indicated that the 25 themes have specifically highlighted the dimensions of Islamic Leadership. Thus, based on the justification, of which the literature selected is Islamic, this research found that the specific 25 themes further explain effective behaviours of Muslim leaders that are cognizant with the dimensions of Maqasid al-Shari'ah.

\section{CONCLUSION}

This research aims to introduce a specific Islamic Leadership Inventories based on the philosophy of Maqasid al-Shari'ah to form a foundation for Islamic Leaders. The specific Islamic Leadership Inventory will also be able to cover three important worldviews of leadership or Islamic Leadership (I-L), Managerial Leadership (M-L), and Servant Leadership (S-L). In this research, Islamic Leadership Inventory and Maqasid al-Shari'ah are regarded as the foundation of ILI, while S-L and M-L were incorporated into ILI to ensure its practicality to be implemented in organisations.

\section{ACKNOWLEDGEMENT}

This research is financed by the Fundamental Research Grant Scheme (Grant No. USIM/FRGS/FKP/32/51813). 


\section{REFERENCE LIST}

Abdul Rashid Moten. (2011). "Leadership in the West and the Islamic World: A Comparative Analysis". World Applied Sciences Journal, 15 (3).

Al-Allaf, M. (2013). Islamic Divine Law (Shariah) The Objectives (Maqasid) of the Islamic Divine Law. Retrieved from http://www.muslimphilosophy.com/ma/works/maqasid.pdf

Al-Fasi, 'Alal. (2011). Maqasid al-Shari'ah al-Islamiyyah wama Karimuha. Kaherah: Dar al-Salam.

Al-Ghali, Balqasam. (1996). Shaykh Muhamad Tahir bin Ashur. Beirut: Dar Ibn Hazm.

Al-Qaradawi, Yusuf. (2006). Dirasah fi Fiqh Maqasid Shariah. Kaherah: Dar al-Shuruq.

Al-Raisuni, Ahmad (2010). Madkhal 'ila Maqasid Shari'ah. Kaherah: Dar al-Salam.

Al-Raisuni, Ahmad. (1992). Nazariat al-Maqasid Inda Imam al-Syatibi. Herndon: IIIT.

Al-Raisuni, Ahmad. (2009). Muhadarat fi Maqasid al-Shari'ah. Kaherah: Dar al-Salam.

Al-Zuhayli, Wahbah. (1418H). Al-Tafsir al-Munir fi al-Aqidah wa al-Shari'ah Wa al-Manhaj. Dimashq: Dar alFikr al-Mu'asir.

Badawi, J., \& Beekun, R. I. (1999). Leadership: An Islamic Perspective. Maryland: Amana Publications.

Bird, J. V., Ji, C.-H. C., \& Boyatt, E. (2004). "Theory Building - Christian Leadership and Relegiosity Reexamined: The Evidence from College Student Leaders". Journal of Research on Christian Education, 13 (2), 225-250.

Braun, Virginia, and Victoria Clarke. (2006). "Using thematic analysis in psychology". Qualitative Research in Psychology, 3 (2).

Frick, D. M., \& Spears, L. C. (Eds.). (1996). On Becoming A Servant-Leader. San Francisco: Jossey-Bass Publishers.

Humphreys, J. H. (2005). Contextual Implications for Transformational and Servant Leadership: A Historical Investigation. Contextual Implications for Transformational and Servant Leadership: A Historical Investigation, 43 (10).

Hunt, J. G. (1991). Leadership: A New Synthesis. London: SAGE Publications.

Ibn 'Ashur, Muhammad Tahir. (2009), Maqasid al-Shari'ah al-Islamiah, Kaherah: Dar al-Salam.

Khaliq Ahmad \& Ogunsola, O. K., (2011) "An Empirical Assessment of Islamic Leadership Principles", International Journal of Commerce and Management, 21 (3).

Khaliq Ahmad. (2011). Management from an Islamic Perspective. Petaling Jaya: Pearson Publication.

Mahazan, A.M., \& Wan Mohd. Fazrul Azdi, W.R. (2012, November). The Concept of Servant and Islamic Leadership: A Comparative Analysis. Paper presented at the International Conference on Islamic Leadership-2 (pp. 227-245). Negeri Sembilan, Malaysia: Universiti Sains Islam Malaysia.

Muhammad Fu'ad 'Abd al-Baqi. (2001). Mu'jam Mufahras Li Alfaz Al-Quran Al-Karim. Cairo: Dar al-Hadith.

Neuman, W. L. (1997). Social Research Methods: Qualitative and Quantitative Approaches. (3 Ed.). Needham Heights Allyn and Bacon.

Shahzad, A., \& Malik, R. K. (2014). "Workplace Violence: An Extensive Issue for Nurses in Pakistan-: A Qualitative Investigation". Journal of Interpersonal Violence, 29 (11).

Shee, S., Ji, C., \& Boyatt, E. (2002). "Religiosity in Christian Educational Leadership". Journal of Research on Christian Education, 11.

Whetstone, J. T. (2002). "Personalism and Moral Leadership: The Servant Leader with a Transforming Vision". Business Ethics: A European Review, 11 (4).

Yukl, G. (1989). "Managerial Leadership: A Review of Theory and Research”. Journal of Management, 15.

Yukl, G., Gordon, A., \& Taber, T. (2002). "A Hierarchical Taxonomy of Leadership Behavior: Integrating a Half Century of Behavior Research". Journal of Leadership and Organizational Studies 9 (1). 
Yukl, Gary. (2013). Leadership in Organizations. New Jersey: Pearson Prentice Hall. 